\title{
PENETRATION OF MOUSE EGGS IN VITRO: OPTIMAL SPERM CONCENTRATION AND MINIMAL NUMBER OF SPERMATOZOA
}

\author{
Y. TSUNODA AND M. G. GHANG \\ Worcester Foundation for Experimental Biology, \\ Shrewsbury, Massachusetts 01545, U.S.A.
}

(Received 21st December 1974)

It is well known that a large number of the spermatozoa in the ejaculate reach the uterus but only a few are found in the oviducts of mammalian species after mating (see Bishop, 1961). This suggests that a small number of spermatozoa competent to fertilize may be selected during their passage through the female tract. In a study of the optimal sperm concentration and the minimal number of spermatozoa required to fertilize a rat egg in vitro, Niwa \& Chang (1974a) have shown that the optimal sperm concentration was about 0.5 to $1.5 \times 10^{6}$ spermatozoa $/ \mathrm{ml}$ and that the minimal number of spermatozoa required to fertilize a rat egg was about 3000 to 6000 spermatozoa. The present experiment was designed to determine the optimal sperm concentration, the minimal number of spermatozoa required to fertilize a mouse egg in vitro, and whether the number of eggs present in each preparation affects the fertilization rate.

The ducts of the cauda epididymidis of a mature Swiss albino mouse were cut with a sharp knife. A small drop of the sperm mass was placed by means of a glass needle into $0.5 \mathrm{ml}$ of a chemically defined medium (Toyoda, Yokoyama \& Hosi, 1971) in a Falcon plastic dish covered with light paraffin oil which had previously been equilibrated with $5 \% \mathrm{CO}_{2}$ in air (original suspension). After 5 to $10 \mathrm{~min}, 0.04 \mathrm{ml}$ of the original suspension was placed in $0.4 \mathrm{ml}$ of the same medium covered with paraffin oil (Suspension 1). In the same way, this sperm suspension was diluted three times (Suspensions 2 to 4 ), and each suspension was preincubated for $1 \mathrm{hr}$ in an incubator at $37^{\circ} \mathrm{C}$ saturated with $5 \% \mathrm{CO}_{2}$ in air.

Mature female Swiss albino mice weighing 23 to $30 \mathrm{~g}$ were injected intraperitoneally with 5 i.u. PMSG and 5 i.u. HCG 44 to $48 \mathrm{hr}$ later. They were killed 15 to $18 \mathrm{hr}$ after the HCG injection and their oviducts were placed under oil in the same dish containing a droplet of sperm suspension. The eggs in cumulus clot were dissected from the ampullary portion of the oviducts with sharp needles; various numbers of eggs were introduced into each sperm suspension, and oviducts and débris were removed from the dishes. After incubation for 3 to $5 \mathrm{hr}$, the eggs were removed, mounted in toto, stained with $0.25 \%$ lacmoid (Chang, 1952), and examined for evidence of sperm penetration and fertilization.

The numbers of spermatozoa in the original suspension and in Suspension 1 were counted by means of a haemocytometer at the end of an experiment but the numbers of spermatozoa in Suspensions 2 to 4 were calculated according to their dilutions and the number found in Suspension 1. 
Table 1. Optimal sperm concentration and minimal number of spermatozoa for fertilization in vitro of mouse eggs

\begin{tabular}{|c|c|c|c|c|c|c|c|}
\hline $\begin{array}{c}\text { Sus- } \\
\text { pensions }\end{array}$ & $\begin{array}{l}\text { Range of } \\
\text { sperm con- } \\
\text { centration } \\
\left(\times 10^{4} / m l\right)\end{array}$ & $\begin{array}{c}\text { Total no. } \\
\text { of sperm. } \\
\left(\times 10^{3} \%\right. \\
0.4 \text { to } 0.44 \\
m l)\end{array}$ & $\begin{array}{c}\text { No. of } \\
\text { eggs } \\
\text { introduced }\end{array}$ & $\begin{array}{l}\text { No. } \\
\text { of } \\
\text { tests }\end{array}$ & Sperm no./egg & $\begin{array}{l}\text { No. of eggs } \\
\text { penetrated/no. of } \\
\text { eggs examined } \\
(\%)\end{array}$ & Total \\
\hline Original & $\begin{array}{c}100 \\
\text { to } \\
860\end{array}$ & $\begin{array}{c}400 \\
\text { to } \\
3,612\end{array}$ & $\begin{array}{c}2 \\
5 \text { to } 6 \\
10 \\
20 \text { to } 40\end{array}$ & $\begin{array}{l}7 \\
7 \\
4 \\
5\end{array}$ & $\begin{array}{c}306,000 \text { to } 1,170,000 \\
80,000 \text { to } 840,000 \\
83,000 \text { to } 202,000 \\
36,000 \text { to } 119,000\end{array}$ & $\begin{array}{cc}12 / 14 & (86) \\
18 / 34 & (53) \\
8 / 38 & (21) \\
31 / 111 & (28)\end{array}$ & $\begin{array}{c}69 / 197 \\
(35)\end{array}$ \\
\hline 1 & $\begin{array}{l}10 \\
\text { to } \\
63\end{array}$ & $\begin{array}{c}40 \\
\text { to } \\
235\end{array}$ & $\begin{array}{c}2 \text { to } 3 \\
5 \text { to } 7 \\
10 \\
20 \text { to } 40\end{array}$ & $\begin{array}{l}6 \\
6 \\
6 \\
8\end{array}$ & $\begin{array}{r}24,000 \text { to } 54,000 \\
8,800 \text { to } 40,000 \\
4,000 \text { to } 18,700 \\
2,000 \text { to } 11,700\end{array}$ & $\begin{array}{cc}8 / 13 & (62) \\
20 / 29 & (69) \\
30 / 54 & (56) \\
154 / 177 & (87)\end{array}$ & $\begin{array}{c}212 / 273 \\
(78)\end{array}$ \\
\hline 2 & $\begin{array}{c}0.52 \\
\text { to } \\
\mathbf{4 . 5}\end{array}$ & $\begin{array}{c}2 \cdot 1 \\
\text { to } \\
19 \cdot 2\end{array}$ & $\begin{array}{l}2 \\
4 \text { to } 6 \\
8 \text { to } 14 \\
17 \text { to } 31\end{array}$ & $\begin{array}{l}6 \\
8 \\
6 \\
5\end{array}$ & $\begin{array}{l}2,200 \text { to } 5,000 \\
670 \text { to } 4,500 \\
250 \text { to } 910 \\
100 \text { to } 840\end{array}$ & $\begin{array}{ll}9 / 12 & (75) \\
25 / 38 & (66) \\
18 / 53 & (34) \\
68 / 114 & (60)\end{array}$ & $\begin{array}{c}120 / 217 \\
(55)\end{array}$ \\
\hline 3 & $\begin{array}{c}0.08 \\
\text { to } \\
0.43\end{array}$ & $\begin{array}{c}0.32 \\
\text { to } \\
1.89\end{array}$ & $\begin{array}{l}2 \\
5 \text { to } 7 \\
9 \text { to } 12 \\
20\end{array}$ & $\begin{array}{l}6 \\
7 \\
7 \\
5\end{array}$ & $\begin{array}{c}200 \text { to } 590 \\
50 \text { to } 328 \\
32 \text { to } 189 \\
16 \text { to } 84\end{array}$ & $\begin{array}{cc}3 / 12 & (25) \\
9 / 36 & (25) \\
25 / 60 & (42) \\
20 / 87 & (23)\end{array}$ & $\begin{array}{c}57 / 195 \\
(29)\end{array}$ \\
\hline 4 & $\begin{array}{c}0.007 \\
\text { to } \\
0.048\end{array}$ & $\begin{array}{c}0.03 \\
\text { to } \\
0 \cdot 192\end{array}$ & $\begin{array}{c}2 \\
5 \text { to } 6 \\
10 \text { to } 12 \\
20 \text { to } 22\end{array}$ & $\begin{array}{l}6 \\
5 \\
4 \\
3\end{array}$ & $\begin{array}{l}18 \text { to } 51 \\
5 \text { to } 29 \\
3 \text { to } 17 \\
2 \text { to } 9\end{array}$ & $\begin{array}{ll}2 / 12 & (17) \\
1 / 24 & (4) \\
2 / 35 & (6) \\
2 / 61 & (3)\end{array}$ & $\begin{array}{c}7 / 132 \\
(5)\end{array}$ \\
\hline
\end{tabular}

Eggs were examined 3 to $5 \mathrm{hr}$ after exposure to epididymal spermatozoa preincubated for $1 \mathrm{hr}$.

It can be seen from Table 1 that the optimal sperm concentration for fertilization in vitro of mouse eggs was about 10 to $63 \times 10^{4}$ spermatozoa $/ \mathrm{ml}$ and that the penetration rates decreased when sperm concentration was decreased or increased, although $5 \%$ of the eggs were penetrated in a suspension of 70 to 480 spermatozoa/ml (Suspension 4). It appears that at least 100 spermatozoa were required to fertilize each egg in order to obtain a penetration rate above $60 \%$ (Suspension 2), although 2 to 84 spermatozoa could fertilize from 3 to $23 \%$ of the eggs (Suspensions 3 and 4 ). There was no striking difference in the penetration rates whether two or twenty eggs were introduced into a sperm suspension ranging from 0.08 to $63 \times 10^{4}$ spermatozoa/ml (Suspensions 1,2 and 3). But the penetration rates were decreased when a large number of eggs were introduced in a low (Suspension 4) or a high sperm concentration (original suspension).

Milovanov \& Sokolovskaya (1945) stated that "both insufficiency and superabundance of spermatozoa have an adverse effect on fertilization". Although capacitation of spermatozoa and fertilization of eggs can be achieved in a relatively high concentration of spermatozoa for the mouse (Iwamatsu \& Chang, 1970; Toyoda et al., 1971), it is clear that an optimal sperm concentration is better for the capacitation of spermatozoa and fertilization of eggs in the mouse (Fukuda, Okada \& Toyoda, 1972), golden hamster (Talbot, Franklin \& Fussell, 1974), and rat (Niwa \& Chang, 1974a, b). In confirmation of these studies, the present experiment has shown that the optimal sperm concentration for fertilization of mouse eggs in vitro was about 0.1 to $0.63 \times 10^{6}$ 
spermatozoa $/ \mathrm{ml}$. Whether such an optimal concentration is for the maintenance of the physiological integrity of spermatozoa, for the capacitation of spermatozoa, or for the penetration of eggs has still to be determined.

The minimal number of spermatozoa required to fertilize a rat egg in vitro was estimated to be 3000 to 6000 (Niwa \& Chang, 1974a), whereas in this study, about 100 to 840 spermatozoa were required to fertilize a majority of the mouse eggs in Suspension 2. The discrepancy may be due to a species difference because mouse spermatozoa appear to withstand manipulation better than rat spermatozoa and the capacitation of mouse spermatozoa in vitro took a shorter time than that of rat spermatozoa (Toyoda et al., 1971; Niwa \& Chang, 1974b). Although there was an indication that the fertilization rate of rat eggs was higher in the presence of a larger rather than a smaller number of eggs (Niwa \& Chang, 1974a), this was not confirmed in the present study on mouse eggs. In addition to the probability of successful collision between gametes (Rothschild \& Swann, 1951), their physiological integrity under certain conditions also seems to be involved.

It has been suggested that due to certain "inexact chiasma formation" during spermatogenesis, only a small proportion of spermatozoa are competent (Cohen, 1969) and the probable selection of a small population of spermatozoa by the female tract of the rabbit has been reported (Cohen \& McNaughton, 1974). Inspection of the raw data (Table 2) revealed that, in the presence of 30 to 84 spermatozoa, or 2 to 42 spermatozoa for each egg, $6(12 \cdot 8 \%)$ of 47 eggs

Table 2. Detailed results following the exposure of various numbers of mouse eggs to minimal numbers of spermatozoa

\begin{tabular}{|c|c|c|c|c|c|}
\hline & $\begin{array}{l}\text { Sperm conc. } \\
\left(10^{4} / \mathrm{ml}\right)\end{array}$ & $\begin{array}{c}\text { Total no. of } \\
\text { sperm. }\left(\times 10^{3} /\right. \\
0.4 \text { to } 0.44 \mathrm{ml})\end{array}$ & $\begin{array}{c}\text { No. of eggs } \\
\text { introduced }\end{array}$ & Sperm no./egg & $\begin{array}{c}\text { No. of eggs penetrated } \\
\text { no. of eggs examined }(\%)\end{array}$ \\
\hline & $\begin{array}{l}0.009 \\
0.013 \\
0.013 \\
0.021 \\
0.021 \\
0.023\end{array}$ & $\begin{array}{l}0.036 \\
0.057 \\
0.057 \\
0.084 \\
0.084 \\
0.101\end{array}$ & $\begin{array}{l}2 \\
2 \\
2 \\
2 \\
2 \\
2\end{array}$ & $\begin{array}{l}18 \\
29 \\
29 \\
42 \\
42 \\
51\end{array}$ & $\begin{array}{l}0 / 2 \\
0 / 2 \\
1 / 2(50) \\
1 / 2(50) \\
0 / 2 \\
0 / 2\end{array}$ \\
\hline Range and Total & 0.009 to 0.023 & 0.036 to 0.101 & 12 & 18 to 51 & $2 / 12(17)$ \\
\hline . & $\begin{array}{l}0.037 \\
0.008 \\
0.023 \\
0.023 \\
0.023\end{array}$ & $\begin{array}{l}0.148 \\
0.032 \\
0 \cdot 101 \\
0 \cdot 101 \\
0 \cdot 101\end{array}$ & $\begin{array}{l}5 \\
6 \\
5 \\
5 \\
5\end{array}$ & $\begin{array}{r}29 \\
5 \\
20 \\
20 \\
20\end{array}$ & $\begin{array}{l}0 / 4 \\
1 / 6(17) \\
0 / 5 \\
0 / 4 \\
0 / 5\end{array}$ \\
\hline \multirow[t]{2}{*}{ Range and Total } & 0.008 to 0.037 & 0.032 to 0.148 & 26 & 5 to 29 & $1 / 24(4)$ \\
\hline & $\begin{array}{l}0.010 \\
0.038 \\
0.007 \\
0.007\end{array}$ & $\begin{array}{l}0.044 \\
0.167 \\
0.030 \\
0.030\end{array}$ & $\begin{array}{l}12 \\
10 \\
10 \\
10\end{array}$ & $\begin{array}{r}4 \\
17 \\
3 \\
3\end{array}$ & $\begin{array}{l}1 / 12(8) \\
0 / 10 \\
1 / 6(17) \\
0 / 7\end{array}$ \\
\hline \multirow[t]{2}{*}{ Range and Total } & 0.007 to 0.038 & 0.030 to 0.167 & 42 & 3 to 17 & $2 / 35(6)$ \\
\hline & $\begin{array}{l}0.008 \\
0.048 \\
0.007\end{array}$ & $\begin{array}{l}0.035 \\
0.192 \\
0.030\end{array}$ & $\begin{array}{l}20 \\
22 \\
20\end{array}$ & $\begin{array}{l}2 \\
9 \\
2\end{array}$ & $\begin{array}{l}0 / 20 \\
1 / 22(5) \\
1 / 19(5)\end{array}$ \\
\hline Range and Total & 0.007 to 0.048 & 0.03 to 0.192 & 62 & 2 to 9 & $2 / 61(3)$ \\
\hline
\end{tabular}


were penetrated in six tests in which penetration had occurred. It is possible that all spermatozoa are at least potentially competent to fertilize. Whether such a fertilized egg can develop normally still requires further investigation. Nevertheless, it appears that the selection of spermatozoa during their passage through the female tract is not necessarily for their fertilizing capacity but for their physiological function as a whole.

This work was supported by a grant (HD 03472) from the U.S. Public Health Service and a grant from the Ford Foundation. One of us (M.C.C.) is a recipient of a Career Award (K6 HD 18,334) from the National Institute of Child Health and Human Development. Sincere thanks are due to Mrs Rose Bartke for assistance.

\section{REFERENCES}

Bishop, D. W. (1961) Biology of spermatozoa. In Sex and Internal Secretions, Vol. II, pp. 707-796. Ed. W. G. Young. Williams \& Wilkins, Baltimore.

Ghang, M. G. (1952) Fertilization of rabbit ova and the effect of temperature in vitro on their subsequent fertilization and activation in vivo. F. exp. Zool. 121, 351-382.

Conen, J. (1969) Why so many sperms? An essay on arithmetic of reproduction. Sci. Prog., Oxf. 57, $23-41$.

Gohen, J. \& McNaughton, D. C. (1974) Spermatozoa: the probable selection of a small population by the genital tract of the female rabbit. 7. Reprod. Fert. 39, 297-310.

Fukuda, Y., OkadA, O. \& Toyoda, Y. (1972) Studies on the fertilization of mouse eggs in vitro. III. Fertilization of denuded eggs by capacitated spermatozoa. Jap. 7. Anim. Reprod. 18, 73-77.

Iwamatsu, T. \& Ghang, M. G. (1970) Further investigation of capacitation of sperm and fertilization of mouse eggs in vitro. F. exp. Zool. 175, 271-282.

Mirovanov, V. K. \& Soxolovskaya, I. I. (1945) Stockbreeding and the Artificial Insemination of Livestock, p. 70. Translation by A. G. Morton. Huchinson's Scientific and Technical Publications, London.

NrwA, K. \& GHANG, M. C. (1974a) Optimal sperm concentration and minimal number of spermatozoa for fertilization in vitro of rat eggs. F. Reprod. Fert. 40, 471-474.

Nrwa, K. \& Ghang, M. C. (1974b) Effects of sperm concentration on the capacitation of rat spermatozoa. F. exp. Zool. 189, 353-356.

Rothschild, LoRd \& Swann, M. M. (1951) The fertilization reaction in the sea-urchin. The probability of successful sperm-egg collisions. 7. exp. Biol. 28, 403-416.

Talbot, P., Franklin, L. E. \& Fusselt, E. N. (1974) The effect of the concentration of golden hamster spermatozoa on the acrosome reaction and egg penetration in vitro. $\mathcal{F}$. Reprod. Fert. 36, 429-432.

Toyoda, Y., Yokoyama, M. \& Hosi, T. (1971) Studies on the fertilization of mouse eggs in vitro. I. In vitro fertilization of eggs by fresh epididymal sperm. Fap. F. Anim. Reprod. 16, 147-151. 